\title{
Evaluation of the Reference Dose Levels in the Chest CT scan
}

\section{Avaliação dos Niveis de Referência de Dose no estudo tomográfico do Tórax}

\author{
Daniel Santos', Nélson Custódio ${ }^{1}$, Paula Madeira ${ }^{2}$, Nuno Matela ${ }^{1}$ \\ 'CBIOS - GQESSE-Gabinete da Qualidade e Estudos Sociais em Saúde Escola Superior de Saúde Ribeiro \\ Sanches, Rua do Telhal aos Olivais, n8 - 8a, 1900-693 Lisboa, \\ ${ }^{2}$ Centro Hospitalar Lisboa Central - Hospital de São José, Rua José António Serrano, 1150-199 Lisboa \\ E-mail:amatela@fc.ul.pt
}

\begin{abstract}
This study was performed in a Hospital in Lisbon, where $30 \mathrm{CT}$ chest scans were evaluated. With this work, we sought to quantify the dosereference level of CT equipment in an hospital focusing the study on the thorax evaluation. It was also intended to quantify an average value for the CT dosimetric quantities, including CTDIw, DLP and effective dose, and then, to compare obtained values with diagnostic reference levels regulated by the ICRP. The dose reference level obtained in the Hospital, for the studied exams was 13,67 mGy. The average CTDIw was $12,18 \mathrm{mGy}$, the mean DLP corresponded to $291,49 \mathrm{mGy} . \mathrm{cm}$ and the average effective dose found was 4 , $95 \mathrm{mSv}$.

This study also allowed to conclude, as predicted, that there is a low risk of cancer occurrence or severe congenital effects in all individuals of the studied sample, and that the effective dose received in each test corresponds approximately to a radiation exposure equivalentto 2,06 years of natural radiation.
\end{abstract}

The average value of all dosimetric quantities did not exceed the limits set by the ICRP.

Keywords: Dosimetric Quantities, Dose, Chest CT scan, Diagnostic Reference Levels, Computer Tomography

\footnotetext{
Resumo

Este estudo foi realizado num Hospital, em Lisboa, onde foram avaliados 30 exames tomográficos de tórax. Com a realização deste trabalho, pretendeu-se quantificar onivel dereferência de dose num dos equipamentos de TC de um Hospital de Lisboa, incidindo na avaliação do estudo do tórax. Pretendeu-se ainda, quantificar um valor médio para as grandezas dosimétricas em tomografia computorizada, nomeadamente o CTDIw, DLP e dose efectiva e, comparar posteriormente, os valores obtidos, com osniveis de referência de diagnóstico regulamentados pelo ICRP. O nivel de referência de dose obtido do Hospital, para os exames estudados foi 13,67 mGy. A média de CTDIw foi $12,18 \mathrm{mGy}$, a média de DLPcorrespondeu a $291,49 \mathrm{mGy} . \mathrm{cm}$ e, a média de dose efectiva apurada foi $4,95 \mathrm{mSv}$.

Com este estudo constatou-se também, que previsivelmente, existe um risco baixo de ocorrência de cancro ou de efeitos hereditários graves em todos os individuos da amostra, e que a dose efectiva recebida em cada exame corresponde, aproximadamente, auma exposição de radiação equivalente a 2,06 anos deradiação natural .

Observou-se que o valor médio de todas as grandezas dosimétricas, não ultrapassou os limites estipulados pelo ICRP.
}

Palavras-chave: Grandezas dosimétricas, Dose, Tórax Tomografia Computorizada, Níveis de Referência de Diagnóstico, TomografiaComputorizada 


\section{Introduction}

The Computed Tomography (CT) was introduced for clinical applications in the early $70 \mathrm{~s}$. In the beginning this technique revolutionized the neurological diagnosis, but soon, tomography expanded its application so that is actually used allover the body. In time, the chest CT scan has proved to be an important alternative to the diagnostic assessment of thoracic pathologies. The approach to the examination of the chest through this diagnostic technique is an asset. since it allowed the production of images with substantial improvement in resolution at low contrast, allowing a morphological and functional analysis of these images, while allowing the thorax study in different planes, not available by conventional methods. As for spatial resolution, there was also a substantial improvement for the evaluation of lung parenchyma.

However, among all imaging diagnostic methods using ionizing radiation, CT is the one that involves greater dose to the patient, and that aspect became a practical handicap.

Awarness about the risk of poor clinical practice, also motivated research on radiation protection precautions used in this type of examination. Consequently, it became necessary to establish dose reference levels in order to use the lowest possible dose in the patient, without interfering with the diagnosis quality, taking into account the ALARA principle "as low as reasonably achievable" , leading to the optimization of practices in terms of patient's radiological protection ${ }^{13)}$. The radiation protection "optimization" is one of the basic principles of radiation protection recommended by ICRP (the International Commissions on Radiological Protection) for medical exposures, along with the principle of justification and limitation.

Thus, there are specific dose reference levels (DRL) for CT examinations set by the ICRP, as indicated in Table 1. These standards are based on specific dosimetric quantities for TC - Computerized Tomography Dose Index Weighted (CTDIw) and dose-length product (DLP). These levels correspond to the reference dose levels for standard examinations performed in patients with average height and body weight $(70 \mathrm{~kg} \pm 3 \mathrm{~kg})^{124}$.

\section{Introdução}

A Tomografia Computorizada (TC) foi introduzida para aplicações clinicas no inicio da década de 70 . Inicialmente, $\mathrm{a}$ introdução desta técnica revolucionou o diagnóstico neurológico, mas em pouco tempo, a técnica tomográfica foi ampliada e passou a ser utilizada nos demais órgãos do corpo humano. Ao longo dos anos o estudo tomográfico do tórax veio a revelar-se um estudo de eleição para a avaliação e análise de patologias torácicas. A abordagem ao exame de tórax através desta técnica de diagnóstico constitui uma mais-valia, uma vez que permitiu a obtenção de imagens, com melhoria substancial da resolução de baixo contraste, fazer uma análise morfológica e funcional dessas imagens, bem como, possibilitou o estudo do tốrax em diferentes planos, até então não reproduzidos pelos métodos convencionais existentes. Quanto à resolução espacial também se verificou uma melhoria substancial, para a avaliação do parênquima pulmonar.

Porém, de todos os métodos de diagnóstico por imagem que utilizam radiação ionizante, a TC é o exame que proporciona maior dose para o paciente, 0 que passou a ser uma contrariedade.

Tendo consciência do risco consequente das más práticas clínicas, tendencialmente crescentes ao longo do tempo, aumentou também a necessidade de investigação no âmbito das precauções quanto à proteç̧ão radiológica utilizada neste tipo de exames. Em consequência, surgiu a necessidade de estabelecer niveis de dose de referência, com o intuito de aplicar a menor dose possivel ao paciente sem interferir com a qualidade do diagnóstico, tendo em conta o principio ALARA "as low as reasonably achievable" promovendo, desta forma, a optimização das práticas em termos de protecção radiológica dos pacientes ${ }^{(1)}$. A "optimização" da radioprotecção constitui um dos principios básicos de Radioprotecção recomendados pelo ICRP (International Comission on Radiological Protection) para as exposiçǒes médicas, juntamente com o princípio da justificação e da limitação.

Assim, existem niveis de referência de dose (NRD), especificos para exames de TC, estipulados pelo ICRP, conforme está indicado pela Tabela 1, em Anexo. Estes niveis de referência fundamentam-se em grandezas dosimétricas especificas para TC: o Indice de Dose ponderada para Tomografia Computorizada (CTDIw) e o produto Dose-Comprimento (DLP). Estes niveis de referência correspondem a niveis de dose para exames típo realizados em pacientes de estatura mediana, com $70 \mathrm{~kg} \pm 3 \mathrm{~kg}$ de massa corporal. ${ }^{(2)}$ 
Table 1 - Reference Doses for CT examinations from different international organizations, (adapted from http://www.icrp.org/docs/DRL_for_web.pdf.)

Tabela 1 - Doses Referẻncia para exames de TC de diversas organizaçôes internacionais, (adaptado de http:/www.icrp.org/docs/DRL for web,pdf.)

\begin{tabular}{|c|c|c|c|}
\hline \multicolumn{4}{|c|}{$\begin{array}{l}\text { Computed Tomography / Tomografia Computadorizad a [Multiple Scan Average Doses (MSAD) } \\
\text { mGy] - International Atomic Energy Agency (IAEA) }\end{array}$} \\
\hline $\begin{array}{l}\text { CT Head } \\
\text { CT Crånio }\end{array}$ & \multicolumn{3}{|l|}{50} \\
\hline $\begin{array}{l}\text { CT Lumbar Spine } \\
\text { CT Coluna Lombar }\end{array}$ & \multicolumn{3}{|l|}{35} \\
\hline CT Abdomen & \multicolumn{3}{|l|}{25} \\
\hline \multicolumn{4}{|c|}{ Computed Tomography [mGy (CTDIw, CTDI) / mGy.cm (DLP)] } \\
\hline & \multicolumn{2}{|c|}{ [CTDIw(slice), then DLP (exam)] } & [CTDI (exam)] \\
\hline & $\begin{array}{l}\text { European } \\
\text { Comission }\end{array}$ & $\begin{array}{l}\text { National Radiological } \\
\text { Protection Board (NRPB) } \\
\text { (UK) }\end{array}$ & $\begin{array}{l}\text { American Association of } \\
\text { Physicists in Medicine } \\
\text { (AAPM) (USA) }\end{array}$ \\
\hline $\begin{array}{l}\text { Routine Head } \\
\text { Crünio (Rotina) }\end{array}$ & 60,1050 & 60,1050 & 60 (head) \\
\hline $\begin{array}{l}\text { Routine Chest } \\
\text { Törax (Rotina) }\end{array}$ & 30,650 & 30,650 & 40(all body sites) \\
\hline $\begin{array}{l}\text { Routine Abdomen } \\
\text { Abdómen (Rotina) }\end{array}$ & 35,780 & 35,800 & \\
\hline $\begin{array}{l}\text { Routine Pelvis } \\
\text { Pélvis (Rotina) }\end{array}$ & 35,570 & 35,600 & \\
\hline $\begin{array}{l}\text { Face \& Sinuses } \\
\text { Face \& Seios Perinasais }\end{array}$ & 35,360 & & \\
\hline $\begin{array}{l}\text { Vertebral Trauma } \\
\text { Vertebral Trauma }\end{array}$ & 70,460 & & \\
\hline $\begin{array}{l}\text { Lung HRCT } \\
\text { HRCT do Pulmão }\end{array}$ & 35,280 & & \\
\hline $\begin{array}{l}\text { Liver and Spleen } \\
\text { Figado e Baço }\end{array}$ & 35,900 & & \\
\hline $\begin{array}{l}\text { Osseous Pelvis } \\
\text { Ossea da Pélvis }\end{array}$ & 25,520 & & \\
\hline
\end{tabular}

The DRL corresponds to the value of the third quartile, or 75 th percentile of the total sample, and is extremely important because trying to keep the dose values always below these benchmarks contributes to a gradual reduction of dose rates. Thus, in future new DRL determination, the value of the third quartile or 75 th percentile of the sample will certainly be less than the value determined in a previous investigation. ${ }^{\text {? }}$ In this context, it should be noted that these reference levels must be met in order to apply good clinical practice, emphasizing the protection of patients and the quality of diagnostic imaging.

The objectives were based on:

1. Establishing a local DRL for the chest CT X-rays performed in the hospital.
Os NRD correspondem ao valor do $3^{\circ}$ quartil, ou ao percentil 75 de uma amostra total, e revelam-se de uma extrema importância, já que ao tentar manter os valores de dose sempre abaixo desses valores de referência contribui-se para uma redução gradual das doses aplicadas. Deste modo, numa determinação futura de novos NRD, o valor do $3^{\circ}$ quartil ou do percentil 75 da amostra será com certeza inferior ao valor apurado numa primeira investigação. ${ }^{(3)}$

Neste contexto, é de salientar que estes niveis de referência devem ser respeitados, no sentido de se aplicar as boas práticas clinicas, dando ênfase à protecção do paciente e à qualidade da imagem de diagnóstico.

Os objectivos basearam-se em:

1. Estabelecer um NRD local, para os exames 
2. Comparing CTDIw values calculated from each examination, with diagnostic reference levels in Europe.

3. Comparing DLP values (only those collected directly from the equipment console), with the European reference levels.

4. Quantifying the actual administered dose during each thorax scan, while comparing this effective dose value with reference dose values described in Table 2 .

5. Fixing the obtained effective dose value and comparing the chest CT procedure with other types of radiological examinations, as is illustrated in Table 2.

6 . Comparing the mean effective dose received during all examinations in the sample, with the amount of natural radiation received by the general population. Results were expressed in equivalent time of exposure to natural radiation.

7. Estimating the risk of cancer or severe congenital effects in individuals exposed to radiation, based on the qualitative classification of the additional risk of cancer, as indicated in Table 3. radiológicos de TC do tórax realizados no Hospital.

2. Comparar os valores de CTDIw, calculados para cada exame, com os níveis de referência de diagnóstico europeus.

3. Comparar os valores de DLP, apenas os recolhidos directamente do equipamento, com os niveis de referència europeus.

4. Quantificar a dose efectiva aplicada em cada exame de tórax, comparando esse valor de dose efectiva, em relação a valores de referênieia de dose, descritos pela tabela 2 , em anexo.

5. Fixar o valor de dose efectiva obtido e comparar o procedimento tomográfico do tórax em relação a outros tipos de exames radiológicos, como se encontra exemplificado na tabela 2.

6. Comparar a dose efectiva $\mathrm{cm}$ média recebida durante todos os exames da amostra, com a quantidade de radiação natural recebida pela populaçăo $\mathrm{em}$ geral, sendo os resultados expressos em tempo equivalente de exposição à radiaçăo natural.

7. Realizar uma estimativa do risco de ocorrência de cancro ou de efeitos hereditários graves, no individuo exposto à radiação, com base na classificaçåo qualitativa do risco adicional de cancro, conforme está indicado na tabela 3.

Table 2 -Effective doses in CT and radiographic examinations (adapted from Ref7)

Tabela 2 - Doses efectivas em exames de TC c radiográficos, (adaptado da Ref 7 )

\begin{tabular}{|c|c|}
\hline $\begin{array}{l}\text { Examination type } \\
\text { Tipos de Exames }\end{array}$ & $\begin{array}{c}\text { Effective dose } \\
\text { Dose Efectiva (mSv) }\end{array}$ \\
\hline \multicolumn{2}{|c|}{$\begin{array}{l}\text { Radiological examinations with } 1 \text { or } 2 \text { incidences } \\
\text { Exames Radiológicos em } 1 \text { ou } 2 \text { incidências }\end{array}$} \\
\hline $\begin{array}{l}\text { Extremities } \\
\text { Extremidades }\end{array}$ & $0.01-0.1$ \\
\hline $\begin{array}{l}\text { Head } \\
\text { Crânio }\end{array}$ & $0.03-0.1$ \\
\hline $\begin{array}{l}\text { Chest (I incidence) } \\
\text { Tórax (uma incidencia) }\end{array}$ & $0.02-0.05$ \\
\hline $\begin{array}{l}\text { Abdomen } \\
\text { Abdomen }\end{array}$ & $0.6-1.1$ \\
\hline $\begin{array}{l}\text { Fluoroscopy } \\
\text { Fluroscopia }\end{array}$ & $6-12$ \\
\hline $\begin{array}{l}\text { Stomach } \\
\text { Estômago }\end{array}$ & $10-18$ \\
\hline $\begin{array}{l}\text { Intestine } \\
\text { Intestino }\end{array}$ & $10-20$ \\
\hline \multicolumn{2}{|c|}{$\begin{array}{l}\text { Computerised Tomography } \\
\text { Tomografia Computorizada }\end{array}$} \\
\hline $\begin{array}{l}\text { Head } \\
\text { Cränio }\end{array}$ & $2-4$ \\
\hline $\begin{array}{l}\text { Spine } \\
\text { Coluna }\end{array}$ & $3-10$ \\
\hline $\begin{array}{l}\text { Chest } \\
\text { Tórax }\end{array}$ & $6-10$ \\
\hline $\begin{array}{l}\text { Abdomen } \\
\text { Abdomen }\end{array}$ & $10-25$ \\
\hline
\end{tabular}


Table 3 -Additional risk of cancer during the life span as a result medical purpose exposure, according to NRPB (National Radiological Protoction Board). (1)

Tabela 3 - Niveis de risco adicional de cancro durante toda a vida resultantes da exposição com propósito médico, segundo o NRPB (National Radiological Protection Board).(1)

\begin{tabular}{|c|c|}
\hline Bert & $\begin{array}{l}\text { Risco Adicional de Cancro } \\
\text { Additional risk of cancer }\end{array}$ \\
\hline $\begin{array}{l}\text { Some days } \\
\text { Alguns dias }\end{array}$ & $\begin{array}{l}\text { Negligible risk - Below I in 1.000.000 people } \\
\text { Risco desprezável - Inferior a } 1 \mathrm{em} 1.000 .000 \text { pessoas }\end{array}$ \\
\hline $\begin{array}{l}\text { Some weeks to a few months } \\
\text { Algumas semanas a poucos meses }\end{array}$ & $\begin{array}{l}\text { Minimum Risk - Between I in } 1.000 .000 \text { people and } 1 \text { in } \\
100.000 \text { people } \\
\text { Risco mínimo - Entre } 1 \mathrm{em} 1.000 .000 \text { e } 1 \mathrm{em} 100.000 \text { pessoas }\end{array}$ \\
\hline $\begin{array}{l}\text { Some months to a year } \\
\text { Alguns meses a um ano }\end{array}$ & $\begin{array}{l}\text { Very Low Risk - Between I in } 100.000 \text { people and I in } 10.000 \\
\text { people } \\
\text { Risco muito baixo - Entre } 1 \text { em } 100.000 \text { e } 1 \text { em } 10.000 \text { pessoas }\end{array}$ \\
\hline $\begin{array}{l}\text { A few years } \\
\text { Poucos anos }\end{array}$ & $\begin{array}{l}\text { Low Risk - Between } I \text { in } 10,000 \text { people and I in } 1.000 \text { people } \\
\text { Risco baixo - Entre } 1 \mathrm{em} 10.000 \mathrm{e} 1 \mathrm{em} 1.000 \text { pessoas }\end{array}$ \\
\hline
\end{tabular}

\section{Materials and Methods}

This study was performed in a Lisbon hospital, equipped with a GE CT Brightspeed with 16 detectors channels.

The study involved 30 patients (19 male and 11 female) over 18 years of age with a body weight between $67 \mathrm{~kg}$ and $73 \mathrm{~kg}$. All other patients who did not fulfill these criteria were excluded from the sample. All procedures respected the Helsinky Declaration principles for biomedical research.

From each patient, gender, weight, age, was registered. Also, technical protocol-related factors, such as, voltage, rotation time, slice thickness, pitch (the same for all patients and presented in Table 4), current intensity, collimation and the values of the dose registered by the dosimetry equipment, including the value of CTDIvol (CTDI volume) and DLP from the equipment console, were also registered.

Descriptive statistical analysis was performed with Microsoft Office Excel (version Office 2003 from Microsoft). CTDIw and effective dose calculation was achieved through the Excel software. The formula used to calculate the CTDIw was based on the following equation:

$$
C T D I_{\text {vat }}=\frac{C T D I_{w}}{p}[\mathrm{mGy}]
$$

\section{Materiale Métodos}

Este estudo foi realizado num Hospital, em Lisboa, equipado com um TC GE Brightspeed com 16 canais de detectores.

A amostra utilizada no estudo é composta por 30 pacientes (19 do sexo masculino e 11 do sexo feminino) com mais de 18 anos de idade e com uma massa corporal, compreendida entre os $67 \mathrm{Kg}$ e os $73 \mathrm{Kg}$. Todos os demais pacientes que não cumpriram estes critérios de inclusão foram excluidos da amostra. Todos os procedimentos tiveram em conta os princípios orientadores de Declaração de Helsínquia para a pesquisa biomédica.

De cada paciente foram recolhidos dados relativos ao sexo, peso, idade, e os factores técnicos aplicados em cada protocolo, como sejam, a tensão, tempo de rotaçăo, espessura de corte, pitch (iguais para todos os pacientes e apresentados na Tabela 4), intensidade da corrente, colimação, e ainda o valor das unidades dosimétricas registadas no equipamento, nomeadamente o valor ce CTDIvol (CTDI volume) $\mathrm{e}$ DLP na consola de aquisição.

Foi realizada uma breve análise estatística descritiva dos dados, com base no programa informático Microsoft Office Excel (versão Office 2003 distribuido por Microsoft). 
where the CTDIvol is the value of CT dose index, provided by the equipment in each exam, and $p$ is the pitch. The effective dose (E) was calculated as the product of normalized effective dose coefficients (EDLP), related to chest examinations, with the DLP. Sowe've got: $\quad E=E^{D L}$.DLP $[m S v] \quad$ w h e r e EDLP coefficients of normalized effective dose used are presented in Table 2 agree with European Standards for Quality Control in Computed Tomography ${ }^{(4)}$.

The calculation of the mean effective dose received, for each examination in terms of time equivalent of natural dose, given in years, involves a quantity, called BERT (Background Radiation Equivalent Time), which sets the ratio between the mean effective dose (E) in $\mathrm{mSv}$ and the average annual dose resulting from exposure to natural sources of radiation in Europe, which according to UNSCEAR93, is $2.4 \mathrm{mSv}$ $/$ year $^{(5)}$, and BERT $=\mathrm{E} / 2.4$ [years]. ${ }^{(6)}$

Table 4-Technical determinants in the examacquisition Tabela 4-Determinantes técnicos da aquisição do exame.
O cálculo do CTDIw e da dose efectiva foi efectuado através do programa Excel. A fórmula utilizada para o cálculo do CTDIw teve como base a seguinte equação:

$$
\mathrm{CTDl}_{\mathrm{w}}=\frac{\mathrm{CTDl_{2 }}}{\rho}[\mathrm{mGy}]
$$

onde, o CTDIvol corresponde ao valor do indice de dose para $\mathrm{TC}$, fornecido pelo equipamento em cada exame, e o pao pitch. Por sua vez a dose efectiva (E) foi calculada através do produto dos coeficientes de dose efectiva normalizada (EDLP), respectiva ao tórax, pela grandeza que caracteriza dosimetricamente cada aquisição, DLP, assim obtémse: $E=E^{\text {DeP }}$.DLP [mSv] em que os valores dos coeficientes de dose efectiva normalizada, EDLP, utilizados, são os apresentados na tabela 2, de acordo com as Normas Europeias de Controlo de Qualidade em Tomografia Computorizada. ${ }^{(4)}$

$O$ cálculo da dose efectiva recebida, em média, por cada exame, em termos de tempo equivalente de dose natural, dado em anos, envolve uma grandeza, designada por BERT, do inglês Background Equivalent Radiation Time, que estabelece a razão entre dose efectiva média (E) em mSv e a dose média anual Europeia resultante da exposição às fontes de radiação naturais, que de acordo com a UNSCEAR93, é $2.4 \mathrm{mSv} / \mathrm{ano}^{(9)}$, sendo que BERT $=\mathrm{E} / 2.4$ [anos ${ }_{.}{ }^{(6)}$

\begin{tabular}{|l|c|}
\hline $\begin{array}{l}\text { Acquisition Mode } \\
\text { Modo de Aquisição }\end{array}$ & $\begin{array}{l}\text { Spiral Acquisition } \\
\text { Aquisição Helicoidal }\end{array}$ \\
\hline $\begin{array}{l}\text { Applied Potential Difference (Kv) } \\
\text { Tensão Aplicada (Kv) }\end{array}$ & 120 \\
\hline $\begin{array}{l}\text { Rotation time (seconds) } \\
\text { Tempo de Rotação (segundos) }\end{array}$ & 0,8 \\
\hline $\begin{array}{l}\text { Slice width (mm) } \\
\text { Espessura de corte (mm) }\end{array}$ & 1,250 \\
\hline Pitch & 1,375 \\
\hline
\end{tabular}

Based on the value calculated in BERT and the classification presented in Table 3 , it was possible to estimate the risk of cancer or severe hereditary effects in individuals of the sample.

The hospital diagnostic reference level obtained for this study is the dose value corresponding to the 75 th percentile of the total sample. As the sample has 30 patients, $75 \%$ of the sample value corresponds to the
Com base no valor apurado de BERT e na classificação da tabela 3 , foi possivel fazer uma estimativa do risco de ocorrência de cancro ou de efeitos hereditários graves, nos individuos da amostra.

O nível de referência de diagnóstico do Hospital, obtido para este estudo, foi o valor de dose correspondente ao percentil $75 \mathrm{da}$ amostra total. Sendo a amostra de 30 pacientes, o valor percentil $75 \mathrm{da}$ 
patient 22.5th, after everyone had been sorted in ascending order of CTDIw. Thus the reference level at diagnosis was calculated using an arithmetic mean between the values of CTDIw of patients 22 th and 23 th. a)

It is noteworthy that we had the possibility to use a computer software CT Dosimetry from Impact-CT, which is based on a Monte Carlo simulation to calculate the dosimetric quantities mentioned above However its use in this study was possible, due to the fact that the program was not prepared for examinations with modulated current and the scanner does not provide information regarding the average current for the entire exam.

\section{Results}

The average effective dose was $4.95 \mathrm{mSv}$, with a standard deviation of $2.07 \mathrm{mSv}$. The minimum dose observed was $2.50 \mathrm{mSv}$ and the maximum value was $10.57 \mathrm{mSv}$ (Table 5). The effective dose received, on average, in each test, roughly corresponds to an exposure equivalent to 2.06 years of natural radiation. For the maximum value of effective dose equivalent exposure corresponds to 4.4 years of natural radiation.

For the specific dosimetric values of TC, the average of all values of CTDIw was $12.18 \mathrm{mGy}$ with a standard deviation of $4.42 \mathrm{mGy}$. The minimum value of CTDIw observed was $7.04 \mathrm{mGy}$, while the maximum was 25.18 mGy. Moreover, the mean DLP values read from the equipment was 291.49 mGy.cm with a standard deviation of 121.75 mGy.cm (Table 6). amostra está associado ao paciente 22,5 , após todos terem sido ordenados por ordem crescente de CTDIw. Desta forma o nível de referência de diagnóstico foi calculado através de uma média aritmética entre os valores de CTDIw dos pacientes $22 \mathrm{e} 23$. ${ }^{(5)}$

É de salientar que tivemos a possibilidade de utilizar um software informático CT Dosimetry da ImPACT-CT que tem por base uma simulação de Monte Carlo para o cálculo das grandezas dosimétricas referidas anteriormente, porém a sua utilização neste trabalho foi impossibilitada, devido ao facto de o programa năo estar preparado para exames com corrente modelada e, de o scanner não fornecer informação do valor médio da corrente para todo o exame.

\section{Resultados}

A média das doses efectivas foi de $4,95 \mathrm{mSv}$, com um desvio padrão de 2,07 . O valor mínimo de dose observado foi $2,50 \mathrm{mSv}$ e o valor máximo foi de $10,57 \mathrm{mSv}$ (Tabela 5). A dose efectiva recebida, em média, em cada exame, corresponde, aproximadamente, a uma exposição equivalente a 2,06 anos de radiação natural. Para o valor máximo de dose efectiva, corresponde uma exposição equivalente a 4,4 anos de radiação natural.

Relativamente aos valores dosimétricos especificos de TC, a média de todos os valores de CTDIw foi $12,18 \mathrm{mGy}$, com um desvio padrão de 4,42 . O valor mínimo de CTDIw observado foi 7,(14 mGy, enquanto que o valor máximo foi 25,18 mGy. Por outro lado, a média de DLP determinada a partir jos valores recolhidos do equipamento, foi de 291.49 mGy.cm, com um desvio padrão de 121,75 (Tabela 6 ).

Table 5 - Effective dose statistical analysis

Tabela 5 - Análise estatística em relação à dose efectiva.

\begin{tabular}{|l|c|c|c|c|c|}
\hline & $\mathbf{N}$ & $\begin{array}{c}\text { Mean }(m S v) \\
\text { Média(mSv) }\end{array}$ & $\begin{array}{c}\text { Standard Deviation } \\
\text { Desvio Padrāo }\end{array}$ & Max & Min \\
\hline $\begin{array}{l}\text { Effective Dose }(\boldsymbol{m S v}) \\
\text { Dose efeetiva }(\mathrm{mSv})\end{array}$ & 30 & 4,95 & 2,07 & 10,57 & 2,50 \\
\hline
\end{tabular}

Table 6 - CTDIw and DLP statistical analysis

Tabela 6-Análise estatistica em relação às variãveis CTDIw e DLP.

\begin{tabular}{|l|c|c|c|c|c|c|}
\hline & N & $\begin{array}{l}\text { Média / Mean } \\
\text { (mGy)/(mGy.cm) }\end{array}$ & $\begin{array}{l}\text { Standard } \\
\text { Deviation } \\
\text { Desvio } \\
\text { Padrão }\end{array}$ & Max & Min & $\begin{array}{l}\text { Reference values CTDIw } \\
\text { (mGy)/(mGy.cm) } \\
\text { Valores de Referéncia }\end{array}$ \\
\hline $\begin{array}{l}\text { CTDIw } \\
\text { (mGy) }\end{array}$ & 30 & 12,18 & 4,42 & 25,18 & 7,04 & 10,65 \\
\hline $\begin{array}{l}\text { DLP } \\
\text { (mGy.cm) }\end{array}$ & 30 & 291,49 & 121,75 & 621,61 & 174,21 & 650,0 \\
\hline
\end{tabular}


In this study, the local DRL, estimated to the CTDIw was $13.67 \mathrm{mGy}$ (Figure 1).
Neste estudo, o NRD local, calculado para a grandeza dosimétrica CTDIw, neste Hospital, foi de 13,67 mGy (Figura 1).

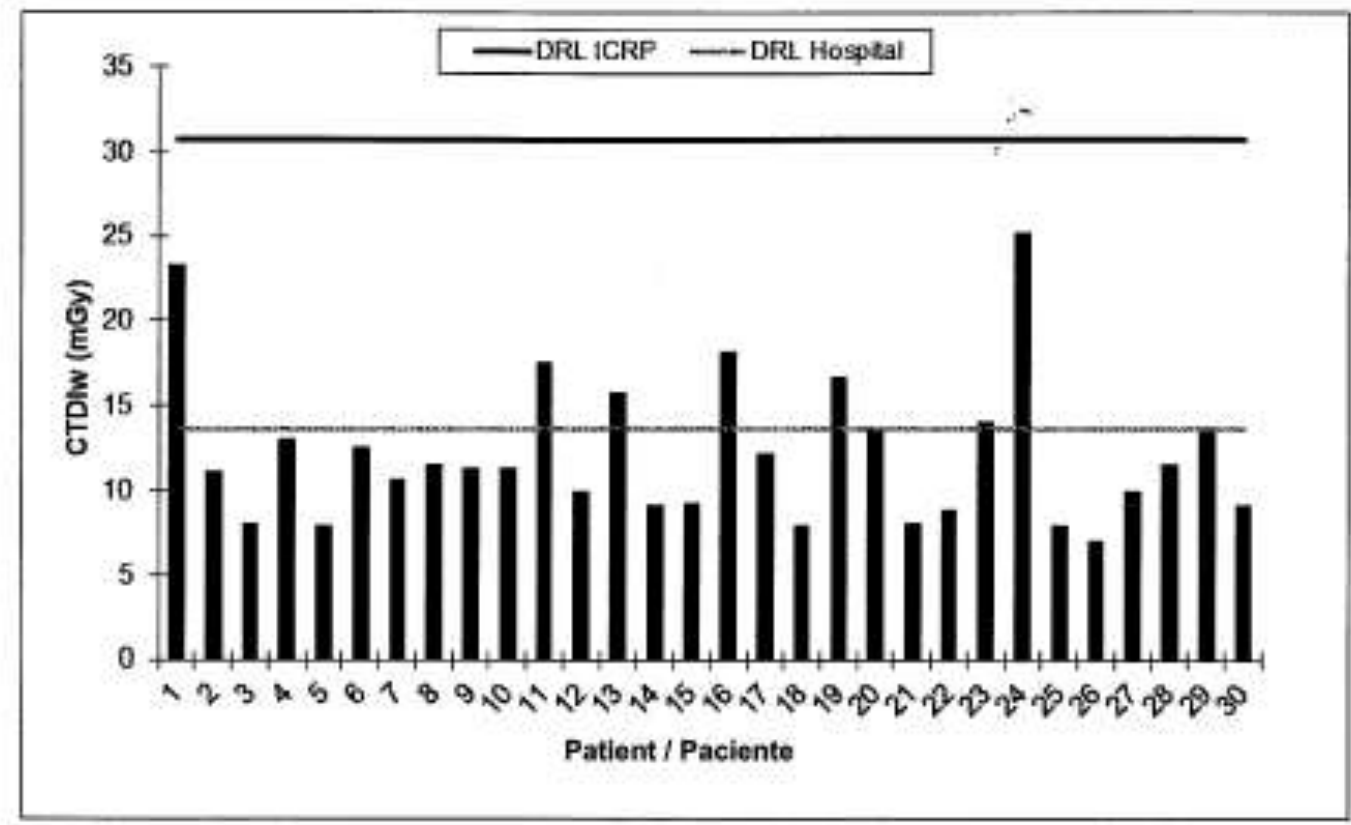

Table 5 - Effective dose statistical analysis

Tabela 5 - Análise estatistica em relaçäo à dose efectiva.

\section{Discussion}

Taking into account the original objectives of this study, we analyzed the values of DLP, CTDIw, effective dose and DRL in this hospital for a chest CT scan performed on a multislice equipment.

According to data, we observed a mean CTDIw below the reference levels set by the European Community (EC). The value of $12.18 \mathrm{mGy}$ found in the experimental study is significantly lower than the value suggested by the EC of $30.65 \mathrm{mGy}$, with a difference of approximately $43 \%$. It is also noteworthy that no CTDIw value exceeded the European reference levels, as shown in Figure 1, but there were two CTDIw values (patients 1 and 24) higher than all the other, probably due to the lungs of these patients being partially filled with pathological liquid, resultingin higher density values and, thereby, higher dose values.

The local DRL value, also estimated for the Hospital, was well below the values defined by the European reference levels.

For the other studied quantity, DLP, it was noted that the mean value provided by the equipment, $291.49 \mathrm{mGy} . \mathrm{cm}$, was still well below (38\%) the value suggested by the European Guidelines $(650.0 \mathrm{mGy}, \mathrm{cm})$.

For effective dose values, a lower mean effective dose 94

\section{Discussão}

Tendo em conta os objectivos iniciais deste trabalho, foram analisados os valores de DLP e CTDIw, Dose efectiva e o NRD neste Hospital, para um estudo Tomográfico do Tórax, realizado num equipamento multicorte.

De acordo com os dados obtidos, observou-se um valor médio de CTDIw inferior aos valores de referência estipulados pela Comunidade Europeia (CE). $\mathrm{O}$ valor encontrado de 12,18 mGy no estudo experimental é significativamente inferior ao valor sugerido de 30,65 mGy pela CE, com uma diferença percentual aproximada de $43 \%$. É de salientar também, que nenhum valor de CTDIw ultrapassou os niveis de referência europeus, como se pode verificar no gráfico 1 , em anexo, porém registaram-se dois valores de CTDIw, nomeadamente nos pacientes 1 e 24 , mais elevados em relação a todos os outros, devído ao facto de os pulmões destes pacientes se encontrarem parcialmente preenchidos com liquido de origem patológica, o que resulta em valores de densidades maiores, aumentando assim, naturalmente, os valores de dose.

Também o valor do NRD local, calculado para o Hospital, encontra-se bastante abaixo dos valores estimados pelos niveis de referência Europeus. 
when compared with other published results was detected 9 . But the average effective dose value determined in this study have shown that for the chest CT scans usually apply higher effective dose values than other radiographic alternative screening examinations, at least for some diagnostic purposes ( Table 2).

Based on calculated values of mean and maximum BERT, and according to the classification suggested by the NRPB in Table 3, it appears that there is a low risk of cancer or severe hereditary effects occurrence in the sample individuals.

For a future research purposes, it is suggested to study local dose levels in other anatomic examinations, so that the Hospital can provide to patients and to health professionals as well, all the information related with the doses received from exposure to natural radiation, as with the local DRL for each examination performed, and compared these data with the European DRL. This will allow to demonstrate that the local values fully agree with the European recommendations.

\section{Conclusion}

This research proved to be of significant importance, since it allowed researchers to create a specific DRL of the hospital regarding the chest CT scan. This is really essential, providing guidance when prescribing and executing a CT examination, but it is also an indicator that should rule health care professionals in risk management.

We believe that radiology is the complementary diagnostic imaging key-technique for the anatomical study of the human being. Thus, to overvaluate it, health professionals should critically use this technique in a conscious and careful way. Imaging is as an asset in terms of diagnosis. However, risk management should be permanently in our minds.

We do hope, by this study, to contribute to the optimization of clinical practice awareness in this area.
Para a outra grandeza estudada, o DLP, notou-se que o valor médio fornecido pelo equipamento, 291,49 mGy.cm, se encontra também bastante inferior $(38 \%)$ ao valor sugerido pelo guia Europeu $(650,0 \mathrm{mGy} . \mathrm{cm})$.

Relativamente aos valores de dose efectiva, foi observado um valor médio inferior acs valores de dose efectiva antes sugeridos ${ }^{n}$. Porém o valor médio de dose efectiva, apurado neste estudo, mostra que nos exames tomográficos de tórax sũo aplicados valores de dose efectiva muito elevados, em relação a exames radiográficos alternativos, enquanto exame de despiste de algumas patologias, tendoem conta a Tabela 2.

Com base nos valores de BERT médio e máximo apurados, e segundo a classificação sugerida pelo NRPB na tabela 3 , verifica-se que existe um risco baixo de ocorrência de cancro ou de efeitos hereditários graves nos indivíduos da amostra.

Para uma próxima investigação neste åmbito, sugere-se que se proceda ao estudo dos niveis de dose locais aplicados em exames de outras regiǒes anatómicas, de forma, a que o Hospital possa disponibilizar aos pacientes e aos profissionais de saúde, um documento em que conste a informação de dose recebida $\mathrm{em}$ anos de exposição à radiação natural, bem como, os NRD locais para cada exame realizadc, em comparação com os NRD Europeus, podendo-se assim, demonstrar que os valores locais obtidos estão de acordo com os valores europeus recomendados.

\section{Conclusão}

Esta investigação revelou-se de substancial importância, uma vez que permitiu, aos investigadores, criar um NRD especifico do Hospital, no estudo tomográfico do tórax. Sendo este, considerado imprescindivel e orientador, aquando da prescrição e consequente realização da TC, constituindo, também, um indicador que deve reger os profissionais de saúde na gestão do risco em saúde.

Consideramos que a radiologia é a técnica complementar de diagnóstico por imagem, de eleição para o estudo anatómico do ser humano, assim torna-se crítico para a sua sobrevalorização, que os profissionais de saúde recorram a esta técnica de modo consciente e criterioso. A imagiologia é, sem qualquer đúvida, uma mais valia em termos de diagnóstico, mas deveremos estar sempre conscientes da gestâo do seu risco.

Esperamos, com a realizaç̆o deste estudo, contribuir para consciencializar para a necessidade de optimização da prática clínica nesta área.

\section{References / Referências}

[1]. Nutional Rodiological Protertion Boerd. Guidelines on Patient Dose to Promole oce Optimizarion of Protection for Diagnestic Medical Exposures. Documents of the NRPB, Report of an Advisary Group on locizing Radistion 1999; 10 (I).

[2], Eurcpean Conmission. Radiatioe grotection 109 . Ouidunoe on diagnostic reference levels for medical esposure. Offsce for official publications of the Eoropean Community, Directorate-Genera
Environment, Noclear Safety and Contl Protection 1999. [3]. Wall BF. Disenostic reference levels in the $X$-ray department. Eur. Radiol. Syllabus 2004; 14:66-73

[4]. European Commission. Qwality eriteria for Compuied Temogragly, OCiee for OBticial publications of the European Communities, EUR 16262. Luxembours: 1999.

[5]. Uniled Nations Sciestific Cormuitiee on the Elfects of Atomic Radiation, Sources and effects of Jonizing
Rediation. Report to the General Assembly of the Uried Nations with Scizntific Anoeves, United Nations saks publication, UNSCEAR: 1993.

[6]. Camersn JR. Aradiation Unit for the Public. Faysics and Society News 1991:20:2.

[ग. Reguils, DF, Eser, H. Patiest exposure in medical X-ray imaging in Europe, Radiat Prot Dosim 2005; 1!4:11.25 